\title{
BMJ Open Bisphosphonates and evidence for association with esophageal and gastric cancer: a systematic review and meta- analysis
}

\author{
Ellen Wright, Peter T Schofield, Mariam Molokhia
}

To cite: Wright $E$, Schofield PT, Molokhia M. Bisphosphonates and evidence for association with esophageal and gastric cancer: a systematic review and meta-analysis. BMJ Open 2015;5:e007133.

doi:10.1136/bmjopen-2014007133

- Prepublication history and additional material is available. To view please visit the journal (http://dx.doi.org/ 10.1136/bmjopen-2014007133).

Received 6 November 2014 Revised 21 September 2015 Accepted 5 October 2015

CrossMark

Department of Primary Care and Public Health Sciences, King's College London, London, UK

Correspondence to Dr Ellen Wright; ellen. wright@kcl.ac.uk

\section{ABSTRACT}

Objectives: Concerns have been raised about a possible link between bisphosphonate use, and in particular alendronate, and upper gastrointestinal (UGI) cancer. A number of epidemiological studies have been published with conflicting results. We conducted a systematic review and meta-analysis of observational studies, to determine the risk of esophageal and gastric cancer in users of bisphosphonates compared with non-users.

Design: We searched PubMed, MEDLINE, EMBASE, Web of Knowledge and Cochrane Database of Systematic Reviews for studies investigating bisphosphonates and esophageal or gastric cancer. We calculated pooled ORs and $95 \% \mathrm{Cls}$ for the risk of esophageal or gastric cancer in bisphosphonate users compared with non-users. We performed a sensitivity analysis of alendronate as this was the most common single drug studied and is also the most widely used in clinical practice.

Results: 11 studies (from 10 papers) examining bisphosphonate exposure and UGI cancer (gastric and esophageal), met our inclusion criteria. All studies were retrospective, $6 / 11(55 \%)$ case-control and $5 / 11$ $(45 \%)$ cohort, and carried out using data from 5 longitudinal clinical databases. Combining 5 studies (1 from each database), we found no increased risk, $O R$ $1.11(95 \% \mathrm{Cl} 0.97$ to 1.27$)$ of esophageal cancer in bisphosphonate users compared with non-users and no increased risk of gastric cancer in bisphosphonate users, OR 0.96 ( $95 \% \mathrm{Cl} 0.82$ to 1.12$)$.

Conclusion: This is the fourth and most detailed meta-analysis on this topic. We have not identified any compelling evidence for a significantly raised risk of esophageal cancer or gastric cancer in male and female patients prescribed bisphosphonates.

\section{INTRODUCTION}

There has been a major rise in the prescribing of bisphosphonates in general and alendronate in particular. In 1992, $0.2 \%$ of women over 40 included in the UK General Practice Research Database (GPRD) were
Strengths and limitations of this study

- Thirteen retrospective studies testing the association between bisphosphonates and upper gastrointestinal cancer have now been published with conflicting results and three meta-analyses also with differing results.

- This is the fourth and most comprehensive meta-analysis, bringing the overall number of negative or no increased risk meta-analyses to three and one positive meta-analysis.

- A particular problem was the use of overlapping cohorts in the same database, which reduced the numbers of studies we were able to combine because of the risk of double counting.

- This study provides additional reassurance to prescribers and users of bisphosphonates but ultimately long term, sufficiently large, prospective studies will be needed to definitively answer this question.

prescribed a bisphosphonate, but by 2005 this had risen to $4.1 \%$ according to Watson et $a l^{1}$ and to between $4.6 \%$ and $4.8 \%$ in the period from 1997 to 2011 in Vinogradova et $a l \mathrm{~s}^{2}$ study. At the same time, there has been a parallel reduction in hormone replacement therapy prescribing from $8.2 \%$ in 1991 to $7.0 \%$ in 2005 , with a $50 \%$ fall since 2002, largely driven by concerns over an excess risk of breast cancer and cardiovascular events. ${ }^{1}$

Bisphosphonates and particularly alendronate are well known to cause both dyspepsia and inflammatory changes such as erosive esophagitis, delayed healing and mucosal abnormalities. ${ }^{3}$ Multinucleated giant cells have been detected in esophageal inflammatory exudates. Whether these can undergo malignant transformation is not known, but concerns have been raised as to a possible link between bisphosphonate use and UGI (upper gastrointestinal) cancer. ${ }^{4}$ 
Since Wysowski's ${ }^{4}$ report to the US Federal Drug Administration in 2009, noting that since the initial marketing of alendronate in 1995, the Federal Drug Administration had received 23 case reports of patients who developed esophageal tumours after taking the drug, there have been a number of observational studies, most in large national databases, looking at a possible association between bisphosphonate use and UGI cancer, but the results have been conflicting. There have also been three published meta-analyses to date, the latest published in 2013. These too have conflicting results with one analysis by Andrici et $a l^{6}{ }^{6}$ showing a significant positive association between bisphosphonates and esophageal cancer, the second by Sun et $a l^{7}$ showing no increased risk, and the third by $\mathrm{Oh} e t a l^{8}$ showing no significant association but indicated a possible increased risk in long-term users of bisphosphonates. In view of the continuing uncertainty, a further review including later, larger studies, Wright et at and Vinogradova $e t a l^{2}$ was indicated. We are mindful of the recent $B M J$ paper by Siontis $e t a l^{10}$ criticising the increasing trend of duplicate meta analyses. We considered this one justified because of: (1) the continuing increased prescribing of these drugs, ${ }^{11}$ (2) the seriousness of the potential adverse effect, and (3) the current uncertainty of the precise effectiveness of these drugs in long-term fracture prevention. ${ }^{12}$

\section{METHODS}

We carried out a systematic review and meta-analysis to test the association between bisphosphonate prescribing and esophageal and gastric cancer. We identified all cohort and case-control and any prospective studies published to that date, assessed the quality of those studies according to preset criteria as described below, compared the risk ratios obtained and where possible combined the results into a meta-analysis to yield a reliable estimate of the risk. The reporting adequacy of each cohort, case-control and cross-sectional study was assessed using the 'Strengthening the Reporting of Observational studies in Epidemiology' (STROBE) statement. For each study, introduction, methodology, results and discussion sections were reviewed and areas of bias, overall interpretation and generalisability of the publication were reported. We followed the MOOSE guidelines for systematic reviews and meta-analyses. For review of study quality including bias, individual studies were reviewed using GRADE guidelines for eligibility criteria, measurement of exposure and outcome, confounders and follow-up. The search and study selection was carried out independently by EW and MM and consensus reached by discussion.

\section{Search strategy}

We searched the following databases-EMBASE, PubMed, MEDLINE, Web of Knowledge (WOK) and Cochrane Database of Systematic Reviews (CDSR) from inception to 30 March 2015 using the terms 'esophageal cancer', 'oesophageal cancer', 'gastric cancer', 'bisphosphonates' and 'alendronate'. The search strings are detailed in the online supplementary material. Language was restricted to English. The abstracts were scanned for retrospective and prospective studies involving adverse effects of bisphosphonates. The reference lists of relevant articles were also hand searched for further studies.

\section{Study selection}

Studies were included if they met the following criteria: (1) the study used a case-control or cohort design; (2) the study examined bisphosphonates and the risk of esophageal and/or gastric cancer; (3) the risk estimate was reported as an OR, HR or relative risk; (4) the $95 \%$ CI for the risk estimate was included. Where there were multiple studies per database we selected a 'best in class' study based on a number of factors including study quality, number of cases, eligibility criteria, measurement of exposure and outcome, confounders and follow-up.

\section{Data extraction}

The data from the studies was extracted onto an electronic standardised form that included author, year of publication, country, source of participants, study type, drugs studied and dosage, age and gender of participants, study population including numbers of exposed and unexposed cases, exclusion criteria, mean years exposure and follow-up, cancer outcome studied, crude and adjusted risk estimates, 95\% CI, variables adjusted for, funding source and additional comments.

Adjusted risk estimates were used in preference to unadjusted estimates, if available. Multiple risk estimates were listed separately for each study and identified separately for differing outcomes and drugs, for example, all bisphosphonates/alendronate and category of cancer: (1) esophageal, (2) gastric or (3) UGI cancer.

\section{Statistical analysis}

The analyses were as follows: (1) esophageal cancer and all bisphosphonates; (2) gastric cancer and all bisphosphonates; (3) esophageal cancer and alendronate; (4) gastric cancer and alendronate; (5) cohort studies-UGI cancer and all bisphosphonates; and (6) case-control studies-UGI cancer and all bisphosphonates.

For each analysis, we selected one study from each database, by consensus, using the following criteria: quality of study, number of exposed cases, adjustment for important confounders and precision of risk estimate. We calculated a pooled OR for the effect of bisphosphonates or alendronate, weighted by study precision. We tested for between-study heterogeneity, where the true underlying effect varies between trials, using Cochrane's Q. This was quantified using the $\mathrm{I}^{2}$ statistic, giving the proportion of overall variation this accounts for. Where the $\mathrm{p}<0.1$ or $\mathrm{I}^{2}>50 \%$, we used a random-effects model to calculate the pooled estimate 
accounting for heterogeneity. Otherwise, we used a fixed-effects model that assumes each study measures the same underlying effect. We carried out sensitivity analyses to examine the effect of substituting alternative studies and/or risk estimates from the same database in the groups. All statistical analyses were carried out using Stata V.13.0 (Stata Corp, College Station, Texas, USA). A funnel plot (see online supplementary figure S1) was used to assess publication bias.

\section{RESULTS}

In total, 412 articles were found to be potentially relevant from the electronic database search (figure 1). Seventy-two abstracts were screened, the remainder rejected as they were review articles, opinion pieces or otherwise not original research. Thirteen studies were initially identified as testing the association between bisphosphonate prescribing and esophageal and/or gastric cancer. One study by Ho $e t a l^{13}$ was rejected as it did not provide any information on the precision of the study, and a further two by Solomon $e t a l^{14}$ and Abrahamsen et $a l^{15}$ as they were letters and not peerreviewed studies, leaving five retrospective cohort studies and six case-control studies (from five papers identified from the literature search). The main characteristics of the individual studies are listed in table 1 . One study by Vinogradova $e t a l^{2}$ actually involved the use of two different UK databases (Clinical Practice Research Data Link Database (CPRD) and Q-Research (QRes)), testing the same association, so has been treated as two studies for the analyses and listed as such in table 1 .

The studies came from five longitudinal clinical databases in four different countries-the USA, the UK, Denmark and Taiwan. In the cohort studies, the number of patients exposed to bisphosphonates varied from 30606 (all UGI cancer, ${ }^{16}$ ) to 55090 (alendronate, Vestergaard ${ }^{17}$ ). In the case-control studies, the number of cases of esophageal cancer varied from $116^{18}$ to $5364 .^{2}$

Studies were selected and grouped for the analyses according to the criteria mentioned in the Methods section. A meta-analysis was performed for each of the groups and sensitivity analyses were carried out to examine the effect of substituting alternative studies and/or risk estimates in the groups. The findings are summarised in table 2 and described below under separate headings for each group.

DNR-Danish National Registries, CPRD (formerly GPRD), QRes database, NHICD—National Health Insurance Claims Database, VAD-Veterans Affairs Database.

\section{Esophageal cancer and all bisphosphonates}

We found no significant association between use of bisphosphonates and esophageal cancer, OR 1.11 (0.97 to 1.27), in the studies selected (figure 2). We performed a number of sensitivity analyses examining different combinations of CPRD studies used; the results essentially were very similar, and all non-significant. An initial sensitivity analysis substituting Wright ${ }^{2}$ as an alternative CPRD study (see online supplementary figure S2.1) found that although the risk ratio increased slightly, the results remained non-significant with an overlapping CI, OR 1.29 (0.97 to 1.72). We then performed further sensitivity analyses substituting Green $e t a l^{20}$ as an alternative CPRD study and Chen $e t a l^{21}$ as the alternative Taiwanese database study (see online supplementary figure S2.2) and found a non-significant pooled risk estimate, OR 1.11 (0.95 to 1.29). In a third sensitivity analysis further substituting Cardwell $e t a l^{19}$ as the CPRD study and Lee $e t a l^{23}$ as the Taiwanese study (see online supplementary figure S2.3), there was no apparent increased risk, OR 1.03 (0.88 to 1.22).

\section{Gastric cancer and all bisphosphonates}

We found no significant association between use of bisphosphonates and gastric cancer (figure 3), OR 0.96 (95\% CI 0.82 to 1.12 ).

\section{Esophageal cancer and alendronate}

We found no increased risk, OR 0.98 (0.87 to 1.11 ), of esophageal cancer in alendronate users (figure 4). We performed three sensitivity analyses-the first substituting Wright $e t a t^{\ominus}$ as the alternative CPRD study and Chen $e t a l^{21}$ as the alternative Taiwanese study (see online supplementary figure S4.1). We found a similar nonsignificant OR 0.97 (0.70 to 1.34$)$. We then substituted Cardwell $e a^{19}$ as the CPRD study (see online supplementary figure S4.2). This resulted in a non-significant risk ratio, OR 0.85 (0.71 to 1.02). The third, substituting Lee $e t a l^{23}$ as the alternative Taiwanese study (see online supplementary figure S4.3) also gave a non-significant risk ratio, OR 0.86 (0.72 to 1.04). Overall, we therefore found no significant association between alendronate and esophageal cancer.

\section{Gastric cancer and alendronate}

We found no increased risk of gastric cancer with alendronate (see online supplementary figure S5), OR 0.99 (95\% CI 0.71 to 1.38 ).

\section{Cohort studies-UGI cancer and all bisphosphonates}

Combining all the cohort studies did not show any significantly increased risk of UGI cancer with bisphosphonates (see online supplementary figure S6), OR 1.32 (95\% CI 0.81 to 2.13$)$.

\section{Case-control studies-UGI cancer and all} bisphosphonates

Combining all the case-control studies also did not show any significantly increased risk of UGI cancer with bisphosphonates (see online supplementary figure S7), OR 1.06 (95\% CI 0.93 to 1.22 ). 
Figure 1 Study selection flow diagram (CDSR, Cochrane Database of Systematic Reviews; WOK, Web of Knowledge).
Total articles identified from database search $(n=412)$

PubMed -331

Embase - 12

Medline - 14

WOK - 55

CDSR - 0
Excluded 344/412 (83\%) as not relevant from title

Excluded 62/72 (86\%) - as not studies, review articles, opinion pieces, letters, duplicates, no confidence intervals (1)

\section{DISCUSSION}

Since the original case reports commented on by Wysowski ${ }^{4}$ in the New England Journal of Medicine, bisphosphonates and the risk of esophageal cancer has been a controversial but important topic, as although esophageal cancer is fortunately rare with UK incidence of 9.7/ $10000,{ }^{24}$ the outcomes are poor and even a small increase in risk would have a significant effect on morbidity and mortality. Other potential harms of bisphosphonates have been raised including increased rates of low-impact femoral fractures, atrial fibrillation and osteonecrosis of the jaw. ${ }^{25}$ At the same time, the effectiveness of bisphosphonates in fracture prevention is being questioned. ${ }^{12}$

We have systematically searched the literature and reviewed all the existing studies testing the association between bisphosphonates and esophageal or gastric cancer and performed a meta-analysis. The results do not support an association between bisphosphonates overall and esophageal or gastric cancer, nor for the sensitivity analyses an increased risk of esophageal cancer in patients prescribed alendronate, a concern raised in the case reports submitted to the US Federal Drug Administration in $2009,{ }^{4}$ although it is possible that studies that examined bisphosphonates as a class in association with UGI cancer risk may have diluted the effect of risks associated with alendronate. Furthermore, sensitivity analyses examining (1) effects of alendronate and (2) substituting different studies from each database for primary and secondary analyses showed largely similar (non-significant) results.

\section{Comparisons with other studies}

Exposure varies with some studies looking at all bisphosphonates combined whereas others look at alendronate alone and some, for example, Vestergaard, ${ }^{17}$ quote individual risk ratios for bisphosphonates (etidronate, risedronate). Length of exposure to bisphosphonates also varies across the studies.

Outcomes of the studies likewise vary-most examined esophageal cancer, some gastric cancer, some ${ }^{16}{ }^{19}$ combining into all UGI cancer and others looking at other gastrointestinal tract cancers ${ }^{20}$ and non-gastrointestinal cancers. ${ }^{17} 2223$ Previous studies have established good validity of READ UGI cancer codes. ${ }^{26}$ However, an additional difficulty is misclassification arising from the lack of precise coding of the histological subtype of esophageal cancer available in primary care records, which were not available for this study. Esophageal adenocarcinoma is thought to be increasing, as a proportion of all esophageal tumours compared with squamous cell, potentially related to the increasing prevalence of gastro-esophageal reflux disease (GORD). It may be difficult to differentiate between esophageal adenocarcinoma and gastric carcinoma at the gastro-oesophageal junction. It would, therefore, be helpful in future studies to be able to link primary care database information to cancer registry data to look at the association between bisphosphonates and particular subtypes of esophageal and gastric cancer.

Thirteen retrospective studies have now been published with conflicting results and three meta-analyses 
Table 1 Characteristics of the studies testing the association between bisphosphonate prescribing and esophageal and gastric cancer or UGI cancer

\begin{tabular}{|c|c|c|c|c|c|c|c|c|c|}
\hline $\begin{array}{l}\text { Author, } \\
\text { country, } \\
\text { year of } \\
\text { publication }\end{array}$ & $\begin{array}{l}\text { Gender } \\
\text { (mean } \\
\text { age, } \\
\text { years) }\end{array}$ & $\begin{array}{l}\text { Study population } \\
\text { (exposed/cases) }\end{array}$ & $\begin{array}{l}\text { Study population } \\
\text { (controls) }\end{array}$ & $\begin{array}{l}\text { nclusion/exclusion } \\
\text { criteria }\end{array}$ & $\begin{array}{l}\text { Follow-up (mean } \\
\text { years) }\end{array}$ & $\begin{array}{l}\text { Outcome } \\
\text { studied- } \\
\text { cancer type/drug } \\
\text { (number of } \\
\text { exposed cases if } \\
\text { quoted) }\end{array}$ & $\begin{array}{l}\text { Risk ratio (p } \\
\text { Value), } 95 \% \mathrm{Cl}\end{array}$ & $\begin{array}{l}\text { Adjusted } \\
\text { variables }\end{array}$ & Comments \\
\hline $\begin{array}{l}\text { Vestergaard, } \\
\text { Denmark, } \\
2011^{17}\end{array}$ & $\begin{array}{l}\mathrm{M}+\mathrm{F} \\
(70.5)\end{array}$ & $\begin{array}{l}\text { Cohort of } 103562 \\
\text { bisphosphonate } \\
\text { users, subset of } \\
53935 \text { (alendronate } \\
\text { users) from Danish } \\
\text { National Registries } \\
\text { including the } \\
\text { National } \\
\text { Pharmacological } \\
\text { Database }\end{array}$ & $\begin{array}{l}310683 \text { age-matched } \\
\text { and sex-matched } \\
\text { controls from the } \\
\text { general } \\
\text { population, } 161207 \\
\text { alendronate-matched } \\
\text { controls }\end{array}$ & $\begin{array}{l}\text { Patients prescribed any } \\
\text { bisphosphonate } \\
\text { between } 1 / 1 / 96 \text { and } 31 / \\
12 / 06 / \text { Prior Gl } \\
\text { malignancy }\end{array}$ & $>5$ & $\begin{array}{l}\text { Esophageal/ } \\
\text { alendronate (14) } \\
\text { Gastric/alendronate } \\
\text { (10) }\end{array}$ & $\begin{array}{l}2.1,1.01 \text { to } 4.35 \\
1.16,0.54 \text { to } 2.53\end{array}$ & $\begin{array}{l}\text { Age, gender, } \\
\text { alcohol, inhaled } \\
\text { bronchodilator or } \\
\text { steroid therapy } \\
\text { (smoking proxy), } \\
\text { antacids, NSAID, } \\
\text { employment, } \\
\text { marital status, } \\
\text { income, prior } \\
\text { gastric surgery }\end{array}$ & $\begin{array}{l}\text { Funded By AP Moller } \\
\text { Foundation, Servier and } \\
\text { Dandy }\end{array}$ \\
\hline $\begin{array}{l}\text { Abrahamsen } \\
\text { et al, } \\
\text { Denmark, } \\
2012^{16}\end{array}$ & $F(79)$ & $\begin{array}{l}\text { Cohort of } 30606 \\
\text { females from } \\
\text { Danish National } \\
\text { Registries between } \\
1995 \text { and 2005, } \\
\text { prescribed } \\
\text { alendronate }\end{array}$ & $\begin{array}{l}122424 \text { patients, } \\
\text { matched } 4: 1 \text { on gender } \\
\text { and year of birth }\end{array}$ & $\begin{array}{l}\text { Women aged } 50 \pm / \text { Prior } \\
\text { hospital diagnosis of } \\
\text { any cancer }\end{array}$ & 3.5 & $\begin{array}{l}\text { UGl/alendronate (44) } \\
\text { Esophageal/ } \\
\text { alendronate (19) } \\
\text { Gastric/alendronate } \\
\text { (22) }\end{array}$ & $\begin{array}{l}0.63,0.45 \text { to } 0.87 \\
0.71,0.43 \text { to } 1.19 \\
0.61,0.39 \text { to } 0.67\end{array}$ & $\begin{array}{l}\text { age, gender, PPI } \\
\text { use, upper } \\
\text { endoscopy, } \\
\text { co-medications, } \\
\text { Charlton } \\
\text { comorbidity index }\end{array}$ & $\begin{array}{l}\text { Researchers have } \\
\text { grants from Merck } \\
\text { (makers of alendronate) } \\
\text { and multiple other drug } \\
\text { companies }\end{array}$ \\
\hline $\begin{array}{l}\text { Cardwell } \\
\text { et al, UK, } \\
2010^{19}\end{array}$ & $\begin{array}{l}M+F \\
(70)\end{array}$ & $\begin{array}{l}\text { Cohort of } 41826 \\
\text { patients on } \\
\text { bisphosphonates } \\
\text { from the UK } \\
\text { General Practice } \\
\text { Research Database }\end{array}$ & $\begin{array}{l}41826 \text { age, sex and } \\
\text { GP practice-matched } \\
\text { controls }\end{array}$ & $\begin{array}{l}\text { Patients treated with } \\
\text { oral bisphosphonates } \\
\text { between January } 1996 \\
\text { and December 2006/ } \\
\text { patients with less than } \\
6 \text { months follow-up }\end{array}$ & $\begin{array}{l}4.5 \\
\text { bisphosphonates/ } \\
4.4 \text { controls }\end{array}$ & $\begin{array}{l}\text { UGl/bisphosphonate } \\
\text { (116) } \\
\text { Esophageal/ } \\
\text { bisphosphonate (79) } \\
\text { UGl/alendronate (55) } \\
\text { Esophageal/ } \\
\text { alendronate (33) }\end{array}$ & $\begin{array}{l}0.96,0.74 \text { to } 1.25 \\
1.07,0.77 \text { to } 1.49 \\
0.79,0.55 \text { to } 1.15 \\
0.77,0.48 \text { to } 1.23\end{array}$ & $\begin{array}{l}\text { Age, gender, } \\
\text { smoking, alcohol, } \\
\text { BMI,GP practice }\end{array}$ & $\begin{array}{l}\text { Funded by CPRD/MRC } \\
\text { licence }\end{array}$ \\
\hline $\begin{array}{l}\text { Green et al, } \\
\text { UK, } 2010^{20}\end{array}$ & $\begin{array}{l}M+F \\
(72)\end{array}$ & $\begin{array}{l}2954 \text { cases of } \\
\text { esophageal cancer, } \\
2018 \text { cases of } \\
\text { gastric cancer, } \\
10641 \text { cases of } \\
\text { colorectal cancer } \\
\text { from the UK } \\
\text { General Practice } \\
\text { Research Database }\end{array}$ & $\begin{array}{l}14770 \text { controls } \\
\text { matched } 5: 1 \text { per case }\end{array}$ & $\begin{array}{l}\text { Men and women aged } \\
40+\text { diagnosed between } \\
1995 \text { and } 2005 \text { with at } \\
\text { least } 12 \text { months } \\
\text { follow-up before } \\
\text { diagnosis/patients } \\
\text { treated with } \\
\text { bisphosphonates } \\
\text { licensed for Paget's } \\
\text { disease or bone } \\
\text { metastases }\end{array}$ & 7.5 & $\begin{array}{l}\text { Esophageal/ } \\
\text { bisphosphonate (90) } \\
\text { Esophageal } \\
\text { (<10 prescriptions) } \\
\text { Esophageal } \\
\text { (>10 prescriptions) } \\
\text { Gastric (49) } \\
\text { Colorectal (276) }\end{array}$ & $\begin{array}{l}1.3,1.02 \text { to } 1.66 \\
0.93,0.66 \text { to } 1.31 \\
1.93,1.37 \text { to } 2.70 \\
0.87,0.64 \text { to } 1.19 \\
0.87,0.77 \text { to } 1.00\end{array}$ & $\begin{array}{l}\text { Smoking, gender, } \\
\text { age, alcohol, BMI }\end{array}$ & $\begin{array}{l}\text { Funded by CPRD/MRC } \\
\text { licence }\end{array}$ \\
\hline $\begin{array}{l}\text { Wright et al, } \\
\text { UK, } 2012^{9}\end{array}$ & $\begin{array}{l}M+F \\
(64.7)\end{array}$ & $\begin{array}{l}5226 \text { cases of } \\
\text { esophageal cancer, } \\
3410 \text { cases of } \\
\text { gastric cancer from } \\
\text { the UK General } \\
\text { Practice Research } \\
\text { Database }\end{array}$ & $\begin{array}{l}20904 \text { and } 13640 \\
\text { controls matched } 4: 1 \\
\text { by age and sex }\end{array}$ & $\begin{array}{l}\text { All men and women } \\
\text { registered with practices } \\
\text { with up to standard data } \\
\text { in the CPRD from } 1995 \\
\text { to } 2007\end{array}$ & 6.1 & $\begin{array}{l}\text { UGl/bisphosphonate } \\
\text { (342) } \\
\text { Esophageal/ } \\
\text { bisphosphonate } \\
\text { (225) } \\
\text { Gastric/ } \\
\text { bisphosphonate (93) } \\
\text { F Esophageal/ } \\
\text { alendronate (95) F }\end{array}$ & $\begin{array}{l}1.3,1.21 \text { to } 1.39 \\
1.43,1.18 \text { to } 1.72 \\
1.06,0.83 \text { to } 1.35 \\
1.42,1.1 \text { to } 1.83\end{array}$ & $\begin{array}{l}\text { Smoking } \\
\text { smoking }\end{array}$ & $\begin{array}{l}\text { Gender difference } \\
\text { identified. Funded by } \\
\text { CPRD/MRC licence }\end{array}$ \\
\hline
\end{tabular}




\begin{tabular}{|c|c|c|c|c|c|c|c|c|c|}
\hline $\begin{array}{l}\text { Author, } \\
\text { country, } \\
\text { year of } \\
\text { publication }\end{array}$ & $\begin{array}{l}\text { Gender } \\
\text { (mean } \\
\text { age, } \\
\text { years) }\end{array}$ & $\begin{array}{l}\text { Study population } \\
\text { (exposed/cases) }\end{array}$ & $\begin{array}{l}\text { Study population } \\
\text { (controls) }\end{array}$ & $\begin{array}{l}\text { nclusion/exclusion } \\
\text { criteria }\end{array}$ & $\begin{array}{l}\text { Follow-up (mean } \\
\text { years) }\end{array}$ & $\begin{array}{l}\text { Outcome } \\
\text { studied- } \\
\text { cancer type/drug } \\
\text { (number of } \\
\text { exposed cases if } \\
\text { quoted) }\end{array}$ & $\begin{array}{l}\text { Risk ratio (p } \\
\text { Value), } 95 \% \text { cl }\end{array}$ & $\begin{array}{l}\text { Adjusted } \\
\text { variables }\end{array}$ & Comments \\
\hline $\begin{array}{l}\text { Vinogradova } \\
\text { et al, UK, } \\
2013^{2}\end{array}$ & $\begin{array}{l}\mathrm{M}+\mathrm{F} \\
(>50)\end{array}$ & $\begin{array}{l}5132 \text { cases of } \\
\text { esophageal cancer } \\
\text { from CPRD } 3157 \\
\text { cases of gastric } \\
\text { cancer }\end{array}$ & $\begin{array}{l}23110 \text { controls } 14686 \\
\text { controls }\end{array}$ & $\begin{array}{l}\text { Patients aged above } 50 \\
\text { with at least } 2 \text { years of } \\
\text { data before index date/ } \\
\text { patients with } \\
\text { prescriptions of } \\
\text { bisphosphonates } \\
\text { licensed for } \\
\text { malignancies, patients } \\
\text { with Paget's disease }\end{array}$ & $\begin{array}{l}\text { Stratified }<6 \\
7-36,37-72 \\
\geq 73 \text { months }\end{array}$ & $\begin{array}{l}\text { Esophageal/ } \\
\text { bisphosphonate } \\
\text { (262) } \\
\text { Esophageal/ } \\
\text { alendronate(167) } \\
\text { Gastric/ } \\
\text { bisphosphonate } \\
\text { (139) } \\
\text { Gastric/alendronate } \\
\text { (100) }\end{array}$ & $\begin{array}{l}1.18(0.09), 0.97 \\
\text { to } 1.43 \\
1.03(0.8), 0.83 \text { to } \\
1.13 \\
0.79(0.06), 0.62 \\
\text { to } 1.01 \\
0.93(0.6), 0.71 \text { to } \\
1.22\end{array}$ & $\begin{array}{l}\text { BMI, smoking, } \\
\text { alcohol, ethnicity, } \\
\text { osteoporosis } \\
\text { history, previous } \\
\text { fracture, steroid } \\
\text { use, H2 } \\
\text { antagonists, PPIs, } \\
\text { antacids, NSAIDs, } \\
\text { vitamin D } \\
\text { prescribed more } \\
\text { than } 1 \text { year before }\end{array}$ & $\begin{array}{l}\text { Nested case-control } \\
\text { using two large national } \\
\text { databases funded by } \\
\text { University of Nottingham }\end{array}$ \\
\hline $\begin{array}{l}\text { Vinogradova } \\
\text { et al, UK, } \\
2013^{2}\end{array}$ & $\begin{array}{l}\mathrm{M}+\mathrm{F} \\
(>50)\end{array}$ & $\begin{array}{l}5364 \text { cases of } \\
\text { esophageal cancer } \\
\text { from Q-Research } \\
\text { database } 3155 \\
\text { cases of gastric } \\
\text { cancer }\end{array}$ & $\begin{array}{l}25101 \text { controls, } \\
\text { matched } 5: 1 \text { by age, } \\
\text { sex, practice and } \\
\text { calendar year } 14715 \\
\text { controls }\end{array}$ & As above & $\begin{array}{l}\text { Stratified }<6 \\
7-36,37-72 \\
\geq 73 \text { months }\end{array}$ & $\begin{array}{l}\text { Esophageal/ } \\
\text { bisphosphonate(252) } \\
\text { Esophageal/ } \\
\text { alendronate(163) } \\
\text { Gastric/ } \\
\text { bisphosphonate } \\
\text { (141) } \\
\text { Gastric/alendronate } \\
\text { (102) }\end{array}$ & $\begin{array}{l}0.97(0.7), 0.79 \text { to } \\
1.18 \\
0.91(0.4), 0.73 \text { to } \\
1.14 \\
1.12(0.4), 0.87 \text { to } \\
1.44 \\
1.47(0.008), 1.11 \\
\text { to } 1.95\end{array}$ & As above & As above \\
\hline $\begin{array}{l}\text { Nguyen et al, } \\
\text { USA, } 2010^{18}\end{array}$ & $\begin{array}{l}97 \% \mathrm{M} \\
(69)\end{array}$ & $\begin{array}{l}116 \text { cases of } \\
\text { incident EAC out of } \\
11823 \text { patients with } \\
\text { BE from the US } \\
\text { Department of } \\
\text { Veterans Affairs } \\
\text { Database }\end{array}$ & $\begin{array}{l}696 \text { controls matched } \\
6: 1 \text { on age }( \pm 5 \text { years) } \\
\text { and BE index date ( } \pm \\
14 \text { days) }\end{array}$ & $\begin{array}{l}\text { Patients aged } 18-90 \\
\text { with ICD code for BE } \\
\text { and endoscopy } 1 \text { year } \\
\text { before BE index date to } \\
9 \text { months after/Pts with } \\
\text { ICD code for EAC } \\
\text { between } 10 / 96 \text { and } \\
6 \text { months after BE index } \\
\text { date }\end{array}$ & $\begin{array}{l}691 \text { days (SD } \\
386)\end{array}$ & $\begin{array}{l}\text { Esophageal/ } \\
\text { alendronate }\end{array}$ & $0.92,0.21$ to 4.15 & & $\begin{array}{l}\text { Completed } \\
\text { bisphosphonate } \\
\text { prescriptions were very } \\
\text { uncommon ( } 1.7 \% \text { in } \\
\text { cases vs } 1.9 \% \text { in } \\
\text { controls) Funding-NIH } \\
\text { and Texas Gulf Coast } \\
\text { Digestive Diseases } \\
\text { Center }\end{array}$ \\
\hline $\begin{array}{l}\text { Chen et al, } \\
\text { Taiwan, } \\
2011^{21}\end{array}$ & $M+F$ & $\begin{array}{l}282 \text { cases of } \\
\text { esophageal cancer } \\
\text { from a cohort of } \\
\text { osteoporosis } \\
\text { treatment initiators } \\
\text { between } 2001 \text { and } \\
2008 \text { from National } \\
\text { Health Insurance } \\
\text { Research Database }\end{array}$ & $\begin{array}{l}2811 \text { controls without } \\
\text { cancer matched by } \\
\text { age, sex and cohort } \\
\text { entry year }\end{array}$ & $\begin{array}{l}\text { Cases hospitalised for } \\
\text { esophageal cancer } \\
\text { since entry into cohort }\end{array}$ & 1 & $\begin{array}{l}\text { Esophageal/ } \\
\text { alendronate (88) }\end{array}$ & $\begin{array}{l}0.61(0.36), 0.21 \\
\text { to } 1.75\end{array}$ & $\begin{array}{l}\text { Age, sex, } \\
\text { comorbidities, PPI } \\
\text { use, cohort entry }\end{array}$ & $\begin{array}{l}\text { Government-funded } \\
\text { research (National } \\
\text { Science Council) }\end{array}$ \\
\hline $\begin{array}{l}\text { Chiang et al, } \\
\text { Taiwan, } \\
2012^{22}\end{array}$ & $\begin{array}{l}F \\
(73.5)\end{array}$ & $\begin{array}{l}\text { Cohort of } 6906 \\
\text { women selected } \\
\text { from NHRI cohort } \\
\text { ( } 1000000 \\
\text { randomly selected } \\
\text { patients of National } \\
\text { Health Insurance } \\
\text { Claims Database } \\
\text { from } 1995 \text { onward })\end{array}$ & $\begin{array}{l}20697 \text { women with } \\
\text { osteoporosis, age and } \\
\text { comorbidity matched, } \\
\text { with no record of taking } \\
\text { bisphosphonates } \\
\text { between } 1996 \text { and } \\
2009\end{array}$ & $\begin{array}{l}\text { Women with } \\
\text { osteoporosis over } \\
\text { 55taking alendronate } \\
\text { from } 1 \text { January } 1998 \text { to } \\
31 \text { December } 2009 / \\
\text { exposure to oral steroids, } \\
\text { malignancy, vitamin D } \\
\text { deficiency, } \\
\text { hyperparathyroidism, }\end{array}$ & 4.8 & $\begin{array}{l}\text { All cancers/ } \\
\text { alendronate (821) } \\
\text { Esophageal/ } \\
\text { alendronate (13) } \\
\text { Gastric/alendronate } \\
\text { (37) }\end{array}$ & $\begin{array}{l}1.05,0.97 \text { to } 1.93 \\
1.5,0.78 \text { to } 2.88 \\
1.04,0.72 \text { to } 1.50\end{array}$ & $\begin{array}{l}\text { Age, gender, } \\
\text { hypertension, } \\
\text { diabetes, COPD, } \\
\text { dyslipidaemia, } \\
\text { CKD, CAD, } \\
\text { colorectal polyp, } \\
\text { benign breast } \\
\text { disease, obesity, } \\
\text { statin use }\end{array}$ & $\begin{array}{l}\text { NHRI cohort is } \\
\text { representative of general } \\
\text { Taiwanese population. } \\
\text { Not controlled for } \\
\text { smoking or alcohol. } \\
\text { Study supported by } \\
\text { grants from National } \\
\text { Science council and }\end{array}$ \\
\hline
\end{tabular}

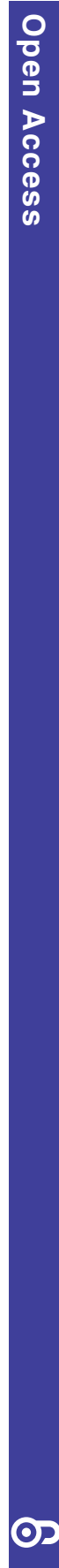

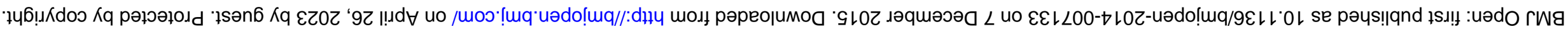




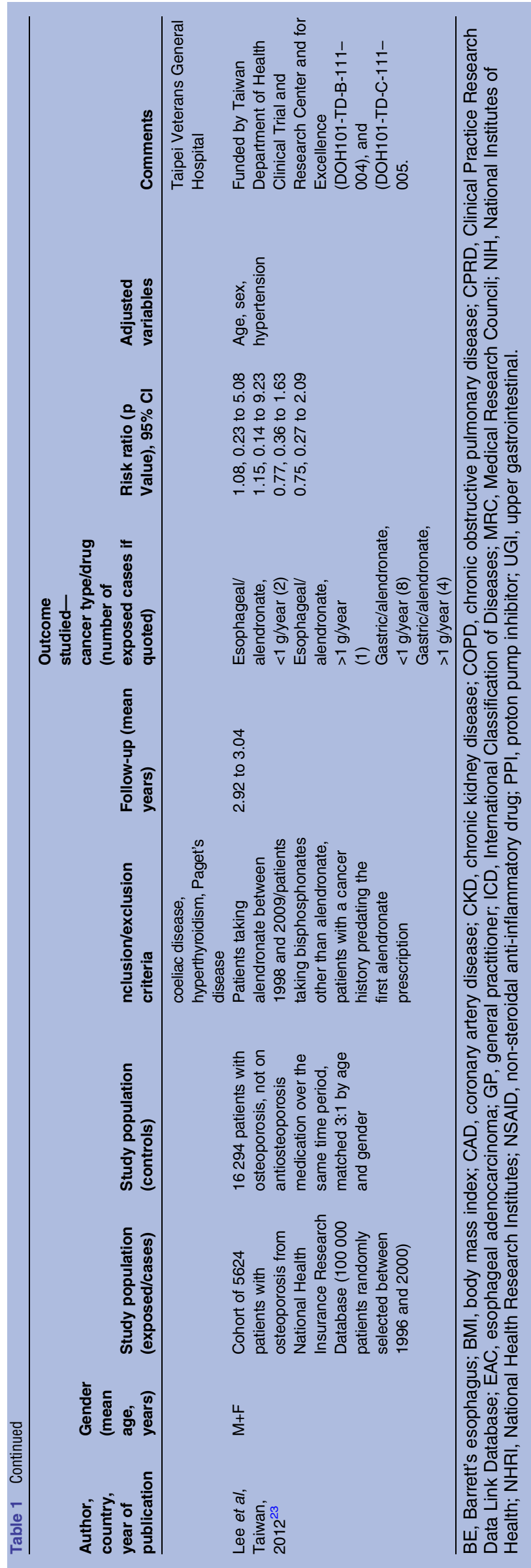

also with differing results. There have been no prospective studies to date. The numbers in the studies vary from very large database studies, 16808 cases of UGI cancer with 5 controls per case, Vinogradova et $a l^{2}{ }^{2}$ to small disease-specific series, 116 cases of esophageal cancer from a cohort of 11823 patients with Barrett's esophagus, Nguyen et al. ${ }^{18}$ With rare cancers, such as UGI cancers fortunately are, it is difficult to obtain the requisite numbers of exposed cases in prospective cohort studies. The Vestergaard ${ }^{17}$ study, by far the largest with a cohort of 103562 bisphosphonate users, still only had 14 esophageal cancer cases exposed to alendronate compared with Wright et $a l \mathrm{~s}^{9} 225$ esophageal cancer cases exposed to bisphosphonates. There was no significant increased risk or difference in risk estimates comparing cohort versus case-control studies overall.

There is significant variation in the confounders that studies adjusted for. Most studies controlled for age, gender and smoking (a major risk factor for UGI cancer), but for reasons that are not clear, none of the Taiwanese studies control for smoking and this limits their validity. Only one study by Vinogradova $e t a l^{2}$ controls for osteoporosis, the risk factors for which overlap with those for UGI cancer, and this is clearly a limitation of other studies. Variation in recording of and accuracy of confounders in the databases is the likely explanation for such discrepancies; however, only database studies using existing information are likely to provide the numbers of cases needed for analysis of the risk of developing a rare disease as a result of drug exposure.

Some studies included patients with mean duration of bisphosphonate use $>5$ years. ${ }^{29}{ }^{20}$ Green et $a l^{20}$ showed an increased risk of esophageal cancer with increasing duration of bisphosphonate use, OR 1.93 (CI 1.37 to 2.70), stratified as $>10$ prescriptions (which is likely to include shorter periods of duration of use). Data from Lee $e t a t^{23}$ examining association of UGI cancer with bisphosphonate annual dosage (bisphosphonate burden $>1 \mathrm{~g}$ ) were inconclusive with wide CIs due to very small numbers. Vinogradova $e t a l^{2}$ stratified by duration of use $>72$ months and showed increased risk of bisphosphonates with esophageal cancer (no increased risk with gastric cancer) in CPRD only, OR 1.63 (1.03 to 2.59); p=0.04 (although authors state this was above the 0.01 significance threshold applied due to the number of comparisons made). Data for esophageal cancer risk with alendronate were stratified only by $\geq 1$ year duration of usage and showed no significant increased risk. Although our previous study had mean duration of use of 6.1 years, we did not stratify risk by duration of use. ${ }^{9}$ Owing to the lack of data (and consistency of long duration exposures), we were unable to examine this formally in the meta-analysis.

\section{Strengths}

There have been three meta analyses to date with conflicting results-one showing an effect, Andrici et al, ${ }^{6}$ and two no effect, Oh $e t a l^{8}$ and Sun $e t a l^{7}$ We focused on extracting data for all bisphosphonates and 
Table 2 Combined estimates and sensitivity analyses for each of the groups

\begin{tabular}{|c|c|c|}
\hline Cancer and drug & Studies & $\begin{array}{l}\text { Combined risk estimate } \\
(95 \% \mathrm{Cl})\end{array}$ \\
\hline $\begin{array}{l}\text { Esophageal cancer and all } \\
\text { bisphosphonates-main analysis }\end{array}$ & $\begin{array}{l}\text { Vestergaard-DNR, Vinogradova-CPRD, } \\
\text { Vinogradova-QRes, Chiang-NHICD, Nguyen-VAD }\end{array}$ & 1.11 (0.97 to 1.27$)$ \\
\hline Sensitivity analysis (1) & $\begin{array}{l}\text { Vestergaard-DNR, Wright-CPRD, Vinogradova-QRes, } \\
\text { Chiang-NHICD, Nguyen-VAD }\end{array}$ & 1.29 (0.97 to 1.72$)$ \\
\hline Sensitivity analysis (2) & $\begin{array}{l}\text { Vestergaard-DNR, Green-CPRD, Vinogradova-QRes, } \\
\text { Chen-NHICD, Nguyen-VAD }\end{array}$ & $1.11(0.95$ to 1.29$)$ \\
\hline Sensitivity analysis (3) & $\begin{array}{l}\text { Vestergaard-DNR, Cardwell-CPRD, Vinogradova-QRes, } \\
\text { Lee-NHICD, Nguyen-VAD }\end{array}$ & 1.03 (0.88 to 1.22$)$ \\
\hline $\begin{array}{l}\text { Gastric cancer and all } \\
\text { bisphosphonates }\end{array}$ & $\begin{array}{l}\text { Vestergaard-DNR, Vinogradova-CPRD, } \\
\text { Vinogradova-QRes, Chiang-NHICD }\end{array}$ & 0.96 (0.82 to 1.12$)$ \\
\hline $\begin{array}{l}\text { Esophageal cancer and alendronate- } \\
\text { main analysis }\end{array}$ & $\begin{array}{l}\text { Abrahamsen-DNR, Vinogradova-CPRD, } \\
\text { Vinogradova-QRes, Chiang-NHICD, Nguyen-VAD }\end{array}$ & $0.98(0.87$ to 1.11$)$ \\
\hline Sensitivity analysis (1) & $\begin{array}{l}\text { Abrahamsen-DNR, Wright-CPRD, Vinogradova-QRes, } \\
\text { Chen-NHICD, Nguyen-VAD }\end{array}$ & 0.97 (0.70 to 1.34$)$ \\
\hline Sensitivity analysis (2) & $\begin{array}{l}\text { Abrahamsen-DNR, Cardwell-CPRD, } \\
\text { Vinogradova-QRes, Chen-NHICD, Nguyen-VAD }\end{array}$ & 0.85 (0.71 to 1.02$)$ \\
\hline Sensitivity analysis (3) & $\begin{array}{l}\text { Abrahamsen-DNR, Cardwell-CPRD, } \\
\text { Vinogradova-QRes, Lee-NHICD, Nguyen-VAD }\end{array}$ & $0.86(0.72$ to 1.04$)$ \\
\hline Gastric cancer and alendronate & $\begin{array}{l}\text { Abrahamsen-DNR, Chiang-NHICD, Vinogradova-QRes, } \\
\text { Vinogradova-CPRD }\end{array}$ & $0.99(0.71$ to 1.38$)$ \\
\hline $\begin{array}{l}\text { Upper GI cancer and all } \\
\text { bisphosphonates }\end{array}$ & $\begin{array}{l}\text { Cohort studies: Vestergaard-DNR, Cardwell-CPRD, } \\
\text { Chiang-NHICD }\end{array}$ & 1.32 (0.81 to 2.13$)$ \\
\hline $\begin{array}{l}\text { Upper } \mathrm{Gl} \text { cancer and all } \\
\text { bisphosphonates }\end{array}$ & $\begin{array}{l}\text { Case control studies: Vinogradova-CPRD, } \\
\text { Vinogradova-QRes, Nguyen-VAD, Chen-NHICD }\end{array}$ & 1.06 (0.93 to 1.22$)$ \\
\hline
\end{tabular}

alendronate as these were the two most common categories studied. Wherever possible, we used the most adjusted estimate available. Our meta-analysis is the largest and most complete one to date which, unlike the others, includes both the latest study using two UK databases (CPRD and QRes) by Vinogradova et $a t^{2}$ and our

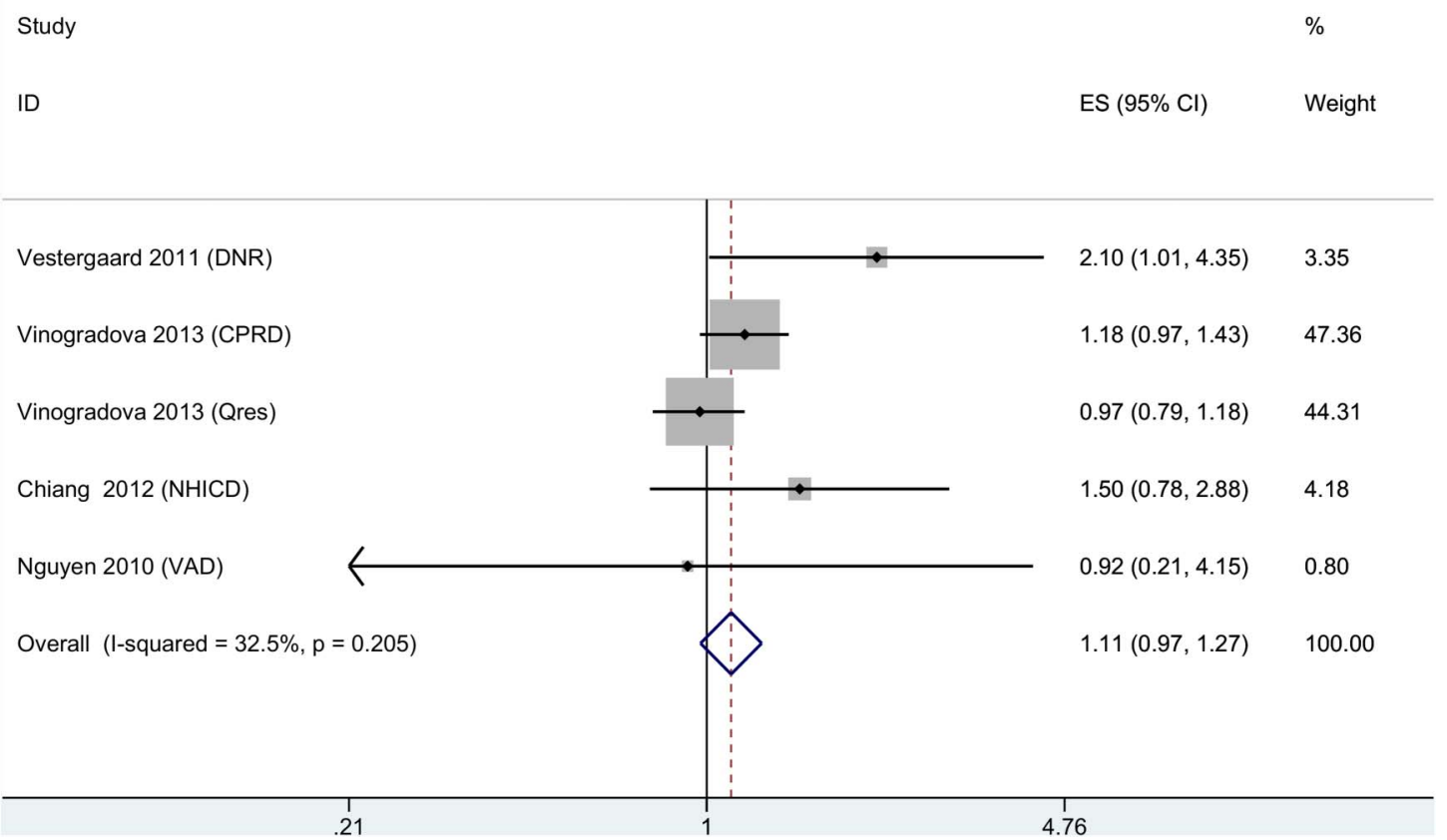

Figure 2 Meta-analysis of risk of esophageal cancer with any bisphosphonate. CPRD, Clinical Practice Research Data Link Database; DNR, Danish National Registries; ES, effect size; NHICD, National Health Insurance Claims Database; Qres, Q-Research; VAD, Veterans Affairs Database. 
Study

ID
$\%$

ES $(95 \% \mathrm{Cl}) \quad$ Weight
$0.79(0.62,1.01) \quad 40.03$

Overall (I-squared $=30.3 \%, p=0.231)$

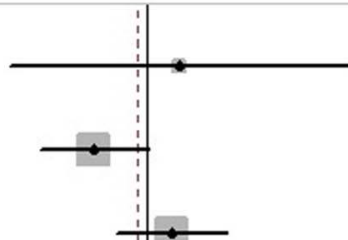

$1.16(0.54,2.53) \quad 4.03$

Vestergaard 2011 (DNR)

Vinogradova 2013 (QR)

Vinogradova 2013 (CPRD)

Chiang 2012 (NHICD)
$1.12(0.87,1.44) \quad 37.82$

$1.04(0.72,1.50) \quad 17.83$

$0.96(0.82,1.12) \quad 100.00$

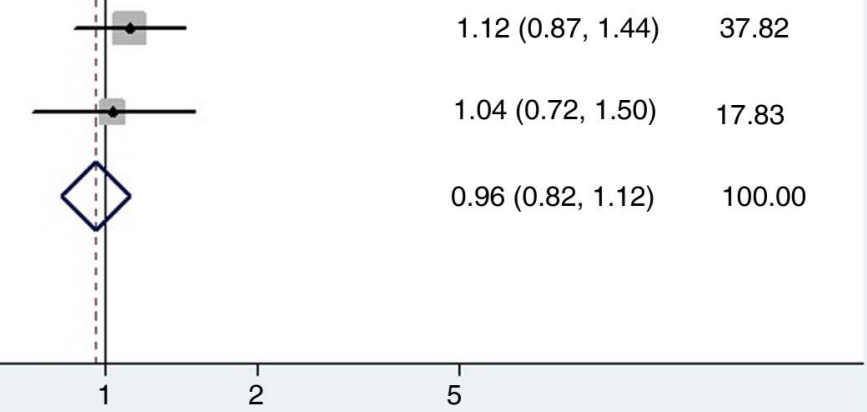

Figure 3 Meta-analysis of gastric cancer with any bisphosphonate. CPRD, Clinical Practice Research Data Link Database; DNR, Danish National Registries; ES, effect size; NHICD, National Health Insurance Claims Database; QR, Q-Research.

own GPRD study by Wright $e t$ al. ${ }^{9}$ For each of our analyses, to avoid double counting we selected one study from each database, by criteria outlined earlier (study quality, number of cases, precision of the risk estimate, adjustment for confounders) to select the best in class.

\section{Limitations}

A particular problem was the use of overlapping cohorts in the same database, which reduced the numbers of studies we were able to combine because of the risk of double counting. For example, there were four studies

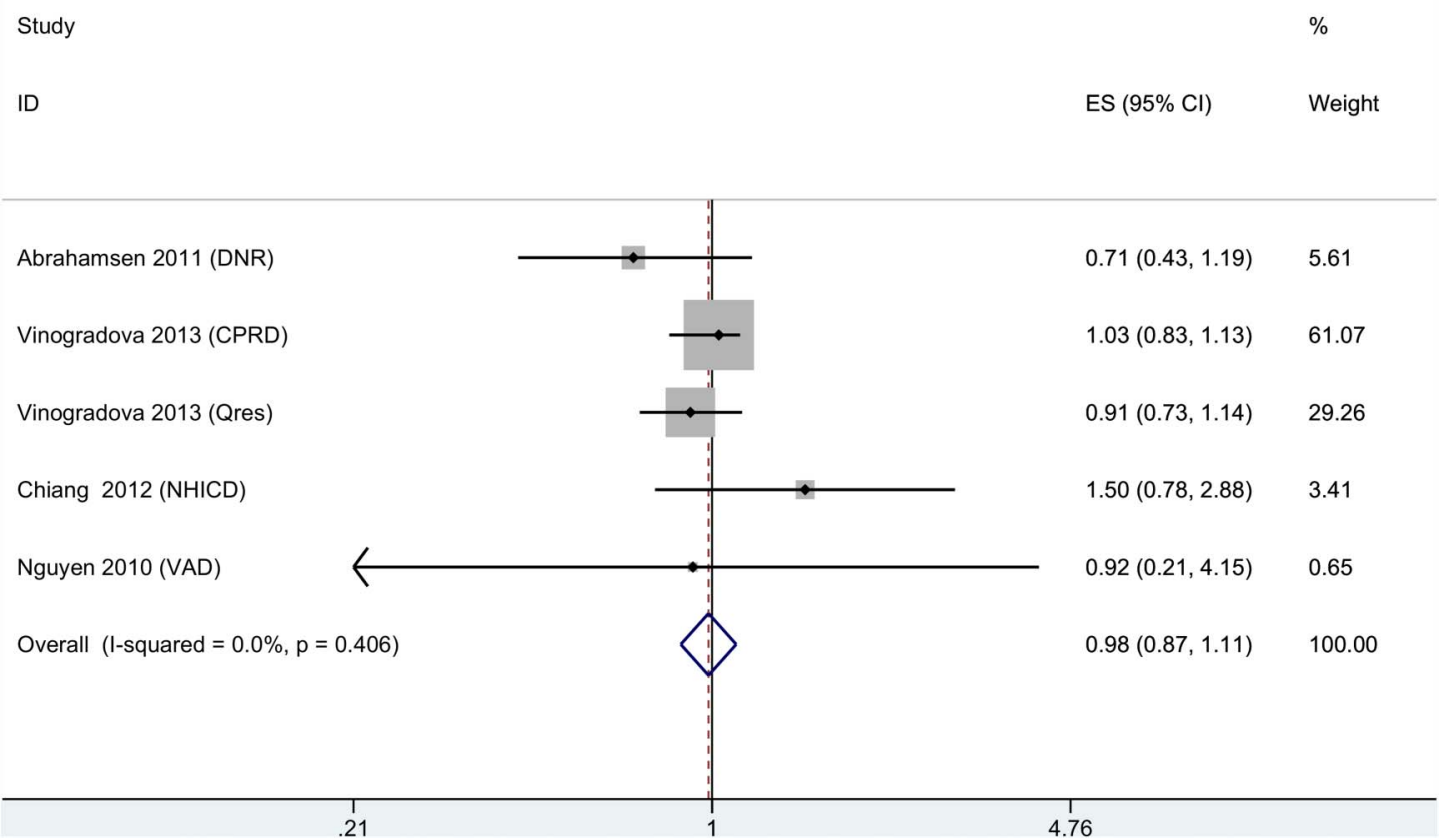

Figure 4 Meta-analysis of risk of esophageal cancer with alendronate. CPRD, Clinical Practice Research Data Link Database; DNR, Danish National Registries; ES, effect size; NHICD, National Health Insurance Claims Database; Qres, Q-Research; VAD, Veterans Affairs Database. 
using the UK CPRD, formerly GPRD, ${ }^{2} 91920$ two studies using the $\mathrm{DNR}^{1617}$ and three studies using the Taiwan NHICD. ${ }^{21-23}$ This necessarily limited the power of the analysis. A further problem that limited the number of studies for meta-analyses including sensitivity analyses, was the differing outcomes and exposures selected.

\section{CONCLUSIONS AND RECOMIMENDATIONS}

There have been three meta-analyses to date with conflicting results. We have added two further studies and followed clear and objective criteria for selection of the best study from each database for the analyses.

Our analyses did not find a significant increased risk between bisphosphonate exposure and gastric or esophageal cancer, or alendronate (the majority of prescribed bisphosphonates) and esophageal cancer. However, we are aware that lack of evidence for an association does not prove the absence of an association.

Bisphosphonates in general and alendronate in particular are being recommended by current osteoporosis prevention guidelines to increasing numbers of men and women in predominantly older age groups. Alendronate is the most commonly prescribed bisphosphonate, and most commonly associated with gastric irritation and erosive esophagitis which could be a plausible mechanism for causation (irritation of the gastric and esophageal mucosa). With a rare disease such as this, very large prospective cohort studies would be required with sufficiently long follow-up to confirm and quantify the associated risk; however, none have been published to date. Despite the inconclusive result of this latest meta-analysis, it would be sensible to exercise caution in prescribing bisphosphonates to patients with pre-existing risk factors for UGI cancer, and to have a lower threshold for investigating such patients, should they develop symptoms suggestive of UGI cancer.

Twitter Follow Ellen Wright at @drellenwright

Acknowledgements The authors are very grateful for the help of Zineb Mehbali in formatting the manuscript.

Contributors EW was involved in original hypothesis and study design, literature search, data interpretation, manuscript preparation and final editing. PTS was involved in main data analysis, study selection, and contributed to final manuscript. MM was involved in data interpretation, study selection and revising article critically for important intellectual content.

Funding National Institute for Health Research (NIHR) Biomedical Research Centre at Guy's and St Thomas' NHS Foundation Trust and King's College London.

\section{Competing interests None declared.}

Provenance and peer review Not commissioned; externally peer reviewed.

Data sharing statement No additional data are available.

Open Access This is an Open Access article distributed in accordance with the Creative Commons Attribution Non Commercial (CC BY-NC 4.0) license, which permits others to distribute, remix, adapt, build upon this work noncommercially, and license their derivative works on different terms, provided the original work is properly cited and the use is non-commercial. See: http:// creativecommons.org/licenses/by-nc/4.0/

\section{REFERENCES}

1. Watson J, Wise L, Green J. Prescribing of hormone therapy for menopause, tibolone, and bisphosphonates in women in the UK between 1991 and 2005. Eur J Clin Pharmacol 2007;63:843-9.

2. Vinogradova Y, Coupland C, Hippisley-Cox J. Exposure to bisphosphonates and risk of gastrointestinal cancers: series of nested case-control studies with QResearch and CPRD data. BMJ 2013;346:f114.

3. Parfitt JR, Driman DK. Pathological effects of drugs on the gastrointestinal tract: a review. Hum Pathol 2007;38:527-36.

4. Wysowski DK. Reports of esophageal cancer with oral bisphosphonate use. N Engl J Med 2009;360:89-90.

5. Wysowski DK. Oral bisphosphonates and oesophageal cancer. BMJ 2010;341:c4506

6. Andrici J, Tio M, Eslick GD. Meta-analysis: oral bisphosphonates and the risk of oesophageal cancer. Aliment Pharmacol Ther 2012;36:708-16.

7. Sun K, Liu JM, Sun HX, et al. Bisphosphonate treatment and risk of esophageal cancer: a meta-analysis of observational studies. Osteoporos Int 2013;24:279-86.

8. Oh YH, Yoon C, Park SM. Bisphosphonate use and gastrointestinal tract cancer risk: meta-analysis of observational studies. World $J$ Gastroenterol 2012;18:5779-88.

9. Wright E, Schofield PT, Seed P, et al. Bisphosphonates and risk of upper gastrointestinal cancer-a case control study using the General Practice Research Database (GPRD). PLoS ONE 2012;7:e47616.

10. Siontis KC, Hernandez-Boussard T, loannidis JP. Overlapping meta-analyses on the same topic: survey of published studies. BMJ 2013:347:f4501.

11. Wang L, Shawn Tracy C, Moineddin R, et al. Osteoporosis prescribing trends in primary care: a population-based retrospective cohort study. Prim Health Care Res Dev 2013;14:1-6.

12. Erviti J, Alonso A, Gorricho J, et al. Oral bisphosphonates may not decrease hip fracture risk in elderly Spanish women: a nested case-control study. BMJ Open 2013;3:pii: e002091.

13. Ho YF, Lin JT, Wu CY. Oral bisphosphonates and risk of esophageal cancer: a dose-intensity analysis in a nationwide population. Cancer Epidemiol Biomarkers Prev 2012;21:993-5.

14. Solomon DH, Patrick A, Brookhart MA. More on reports of esophageal cancer with oral bisphosphonate use. $N$ Engl J Med 2009;360:1789-90.

15. Abrahamsen B, Eiken P, Eastell R. More on reports of esophageal cancer with oral bisphosphonate use. N Engl J Med 2009;360:1789, author reply 91-2.

16. Abrahamsen $\mathrm{B}$, Pazianas $\mathrm{M}$, Eiken $\mathrm{P}$, et al. Esophageal and gastric cancer incidence and mortality in alendronate users. $J$ Bone Miner Res 2012;27:679-86.

17. Vestergaard P. Occurrence of gastrointestinal cancer in users of bisphosphonates and other antiresorptive drugs against osteoporosis. Calcif Tissue Int 2011;89:434-41.

18. Nguyen D, Schwartz J, Richardson P, et al. Oral bisphosphonate prescriptions and the risk of esophageal adenocarcinoma in patients with Barrett's esophagus. Dig Dis Sci 2010;55:3404-7.

19. Cardwell CR, Abnet CC, Cantwell MM, et al. Exposure to oral bisphosphonates and risk of esophageal cancer. JAMA 2010;304:657-63.

20. Green J, Czanner G, Reeves G, et al. Oral bisphosphonates and risk of cancer of oesophagus, stomach, and colorectum: case-control analysis within a UK primary care cohort. BMJ 2010;341:c4444.

21. Chen YM, Chen DY, Chen LK, et al. Alendronate and risk of esophageal cancer: a nationwide population-based study in Taiwan. J Am Geriatr Soc 2011:59:2379-81.

22. Chiang $\mathrm{CH}$, Huang $\mathrm{CC}$, Chan WL, et al. Oral alendronate use and risk of cancer in postmenopausal women with osteoporosis: a nationwide study. J Bone Miner Res 2012;27:1951-8.

23. Lee WY, Sun LM, Lin MC, et al. A higher dosage of oral alendronate will increase the subsequent cancer risk of osteoporosis patients in Taiwan: a population-based cohort study. PLOS ONE 2012;7:e53032.

24. CancerResearchUK. Cancer Statistics. http://info.cancerresearchuk. org/cancerstats/

25. Kuehn BM. Long-term risks of bisphosphonates probed. JAMA 2009;301:710-11.

26. Khan NF, Harrison SE, Rose PW. Validity of diagnostic coding within the General Practice Research Database: a systematic review. $\mathrm{Br} J$ Gen Pract 2010;60:e128-36. 